\title{
Making up families : how DNA analysis does/does not verify relatedness in family reunification in Finland
}

\section{Tapaninen, Anna-Maria}

2020-09

Tapaninen , A-M \& Helen , I 2020 , ' Making up families : how DNA analysis does/does not verify relatedness in family reunification in Finland ', BioSocieties, vol. 15 , no. 3 , pp. 376-393 . https://doi.org/10.1057/s41292-019-00148-6

http://hdl.handle.net/10138/326156

https://doi.org/10.1057/s41292-019-00148-6

submittedVersion

Downloaded from Helda, University of Helsinki institutional repository.

This is an electronic reprint of the original article.

This reprint may differ from the original in pagination and typographic detail.

Please cite the original version. 
Pre-print version of an article published AOP in BioSocieties (2019) doi: 10.1057/s41292-019-00148-6

\title{
Anna-Maria Tapaninen \& Ilpo Helén
}

\author{
Making up families \\ How DNA Analysis Does/Does Not Verify Relatedness in Family Reunification in \\ Finland
}

\begin{abstract}
This article examines the role of DNA testing in immigration management practices in which individuals and their kin relationships are modified as objects of investigation: defined, categorised and "made up" (Hacking 2002) as families. Analysis focuses on the interplay of documents (or lack thereof), narratives and DNA analysis that produces evidentiary facts and knowledge about migrants and, simultaneously, forges relationships between individuals, families and other collectives. Analysis of the Finnish administrative and legal data concerning family reunification shows that DNA testing does much more than just provide evidence of the existence of a genetic tie between alleged family members; testing can also be translated into proof of 'true' families or extended to test the credibility of the applicants. Via translations and extensions, the accuracy of DNA analysis is intertwined with the contingencies of decision-making in the context of immigration management. Related to this, the article demonstrates that DNA testing supports the process by which immigration authorities in the Global North constitute the family as contingent, indefinite and even arbitrary, rather than consolidating a clear and solid model of eligibility for family reunification.
\end{abstract}


Introduction

Family reunification has become a major route to legal, long-term immigration into Europe in the $21^{\text {st }}$ century (EMN 2017; Eurostat 2016). It is based on "the right to family", as laid down in international conventions (Ruffer 2011; Heinemann et al. 2013), and managed and regulated through administrative procedures in which national immigration authorities investigate, case by case, whether or not "there is a family to reunify", as one Finnish immigration official put it. Immigration authorities utilize DNA testing in family reunification procedures in at least 25 countries in the Global North (EMN 2016, 2017). It has become a routine form of investigation in immigration management (EC 2012; EMN 2009; 2012; 2016), as it is widely perceived to provide the most exact and objective piece of evidence in the verification of family ties (Heinemann et al. 2015). The results, expressed in the language of probabilistic approximations, can in principle either confirm or refute claims of family ties. However, DNA testing is mostly conducted in relatively nebulous terrain, as policies in which biotechnologies are embedded vary between countries and across time (Taitz et al. 2002; Ruffer 2011; La Spina 2012; Heinemann et al. 2013).

The existing literature has mostly approached DNA testing for family reunification from the perspectives of legal studies, human rights and ethics. Recurring themes have included the issue of a biological versus a social definition of the family (Taitz et al. 2002; Murdock 2008; UNHCR 2008; Eshenshade 2010; Villiers 2010; Holland 2011) and the geneticisation of the family via DNA testing (Heinemann and Lemke 2012; 2015). Also attracting research interest are the ethical implications of DNA testing in terms of informational privacy and discrimination (Weiss 2011; Dove 2015). DNA analysis in the context of immigration has also been studied as related with a specific form of biological citizenship (Heinemann and Lemke 2014; Helén 2014).

In this paper, we study DNA testing for family reunification as part of a procedure in which families are constructed, reconstructed and performed: in other words made up (Hacking 2002; 2007) as legal, administrative, social and biological entities. However, the family is not the primary topic of our study; rather, we focus on the emergent, evasive dynamics by which the technology of DNA analysis has become entwined with the control and decision-making practices of immigration management. We do not discuss the consequences or outcomes of the use of technology, or analyse 
the kind of families immigration management posits as eligible for reunification. Hence, we are not primarily interested in the biological bias of the family concept in European migration policy or the "geneticisation" of the family (cf. Heinemann and Lemke 2012, 2015); rather, we analyse the process of making up families: elements, rationales, orders and trajectories. What does DNA testing $d o$ in the practices and procedures of immigration management in order to modify individuals and their relationships as objects of investigation, to be defined, categorised and made verifiable - made up - as families?

We focus on the making and weighing of facts and knowledge as evidence. This, in turn, is at the centre of policies and administrative measures that aim to sort "legible persons" (Scott 1999: 65) out of immigrant "flows". Today, immigration authorities in the Global North deploy biotechnologies and biometrics to accomplish this task (Dijstelbloem and Meijer 2011), which, in addition to DNA testing, include fingerprinting and the related EURODAC database (van der Ploeg 1999), medical examination for signs of torture (Fassin and d'Halluin 2005), and medical ageassessment of alleged minors (EMN 2010; Smith and Brownlees 2011; Nol 2015). With the help of these technologies, the migrant body can be made "readable" by translating it into biological and statistical information (van der Ploeg 1999, 2012); these "bodies that do not lie" (Aas 2006: 156) can allegedly provide accurate and objective proof that supports or counts against the person's application for asylum or family reunification. DNA analysis as part of family reunification investigations is widely perceived as providing the most exact and objective form of knowledge about family ties in the administrative, legal and political contexts of immigration management. Yet it is highly specific and more complicated than it seems, because it concerns relational identities that are embedded in the complex dynamics of relatedness and cannot be reduced to the concept of a bounded, generic family.

In this paper, we claim that, despite its praised objectivity and exactness, DNA analysis is an ambiguous device in terms of immigration management. We demonstrate that DNA testing does much more than just provide evidence, facts and knowledge contributing to the verification of the existence of a genetic tie between alleged family members, because DNA analysis is translated and extended when deployed for family reunification. That is, evidence of genetic relatedness can be translated into proof of the existence of 'true' families and a source of credibility for applicants - or, alternatively, it can be passed over. Another form of translation is the way other pieces of evidence, interviews in particular, may both reflect and resist the criteria of verification established in DNA analysis. By 'extensions' we refer to the possible stretching of the use of parental testing beyond the 
actual verification of genetic relatedness. The 'exact' DNA evidence, inscribed in the language of probabilities, can spill over the edges of the intentions of legislation and have shifting, even unexpected consequences.

Translations and extensions of DNA analysis in family reunification exemplify a more general feature of investigations of migrating people. The procedures of interrogation and search for evidence forge ties between individuals and human collectives - the family, of course, but also other kinds of collectives based, for example, on ethnic group and the degree of suspicion it faces in the host country. To understand what DNA testing does, we have to investigate the collectives to which the applicants are attached during family reunification processes. What kind of collectives are they? How does the application of DNA analysis and other forms of evidence make them up, and how are they connected? Moreover, due to the translations and extensions of DNA test findings, the accuracy of laboratory analysis is intertwined with the contingencies of decisionmaking; we go further to claim that the potential for flexible usage is intrinsic to the practice of DNA testing in the context of immigration management. To understand the malleability of the use of DNA testing and proof it provides, the key question is the following: If DNA testing is an answer, what are (or could be) the questions? What are the components of the maze of uncertainties to which the testing is directed within the dynamics of family reunification? How do facts evolve, and how are they constructed during the process?

Our study is firmly set in the context of Finland because Finnish practices of family reunification provide good examples of the translations and extensions of DNA testing. Data are drawn from legislative and administrative documents, interviews with experts (in immigration management, laboratories, NGOs and law firms) and the applicants concerned, and examination of appeals to the Administrative Court of Helsinki between 2003 and 2014. ${ }^{1}$ Our analysis of 'case Finland' demonstrates particularly well how the 'exact' results of DNA analyses enmesh with contingencies of administrative and legal decision-making. Furthermore, our data highlight the interplay between different forms of evidence - documents (or lack thereof), narratives of the applicants' interviews and DNA analysis - which is of special relevance in the decision-making of the Finnish

\footnotetext{
${ }^{1}$ Our analysis here is based on our work in two research projects: first, DNA and Immigration (2009-2012, ELSA GEN 2009-12) and, second, Bodies of Evidence (2014-2018, Kone Foundation). The analysed archival material collected in these two projects consists of policy documents, draft laws, statements given by the authorities to the Finnish Parliament, NGO materials and appeal court cases; secondly, data were drawn from 39 interviews with immigration authorities, representatives of NGOs, geneticists and forensic doctors, lawyers, representatives of underage sponsors, and people whom family reunification concerns personally or as members of collectives.
} 
immigration authorities. The administrative and political milieu of Finnish immigration management is characterized by ubiquitous suspicion (Tapaninen and Helén 2015). Therefore, all pieces of evidence are examined for their credibility and, by the same token, for the applicants' overall credibility. The pursuit of unquestionable verification manifests itself in the intricate compilation of proof, reflecting the context of distrust by both dispelling and heightening it. In Finland, DNA analysis is only a partial answer to the question of whether a family exists - or not an answer at all, because the results can be ignored or option of parental testing may not even be offered at all (Tapaninen and Helén 2015; Tapaninen et al. 2017; Halme-Tuomisaari et al. 2018).

In the following section we describe the close connection between the Somali question and the application of DNA testing in Finland whereby the collective categories of 'Somalis' and 'suspect refugees' are made up and accentuated. We continue by clarifying how genetic relatedness can be translated into proof of family ties and, therefore, the trustworthiness of the applicants. We then move on to discuss how the perceived factualness of DNA analysis is translated into the search for further facts via interviews. In conclusion, we extend our analysis of transformations in immigration regimes and discuss the changing role of DNA analysis in Finland after recent restrictions in immigration policy.

\section{'Closer to the truth': DNA analysis and the Somali question}

DNA testing for family reunification was introduced to the Finnish immigration administration in the late 1990s and incorporated into immigration legislation in 2000. As shown by Tapaninen and Helén (2015), the initiation of DNA testing in Finland was related to a sudden increase of asylum seekers from Somalia. The Finnish immigration authorities considered DNA analysis a means to solve the problem of numerous pending, presumed 'unfounded', applications of Somali nationals with a refugee background; the authorities hoped that "DNA testing could get us to the truth or closer to the truth", as one Finnish immigration official formulated it. Ever since, deployment of DNA testing has mostly targeted Somali applicants. This is clearly shown in the legal domain: of 253 cases on family reunification in the Administrative Court of Helsinki that reference the term DNA in 2003-2014, more than 70 per cent concerned Somali nationals (Halme-Tuomisaari et al. 2018; Tapaninen et al. 2017).

Since implementation of DNA testing for family reunification was entwined with the making of the Somali question in Finland, it provides an example of the co-production of technology and politics (Jasanoff 2004). It was hoped that pursuing the truth through DNA analysis would help manage the 
'flood' of Somali refugees, and even today this link reinforces the general dynamics of doubt and proof, to the extent the Somalis still embody the problems of immigration and family reunification. ${ }^{2}$ The availability of a biotechnological method of investigation has definitely increased distrust felt towards the applicants, and the topic of family reunification easily evokes perceptions of ubiquitous fraud. One lawyer encapsulated this this by saying that "in the case of Somalis, everything is suspect”. By all accounts, positive decisions on applications are almost always based on positive results of a DNA analysis. More generally, the routine deployment of DNA analysis implies the existence of a collective of suspect refugees, as people with a refugee background are most likely to be directed to the laboratories.

The amendments to the Aliens Act in 2000 concerning DNA testing were passed with an unambiguous consensus. The principles of voluntariness, data protection, informed consent and public funding were believed to safeguard the rights of the applicants. It was considered the last resort after all other investigations were deemed inadequate, and pursuant to Section 65 (1) of the Aliens Act, was obviously only an option "if it is possible to obtain material evidence of the family tie through DNA analysis".

Two decades after its initiation, DNA testing has become an integral part of decision-making, especially in cases in which the sponsor's resident permit is based on international protection. Normalisation of the testing is grounded on consensual views, unaltered legislation and the established forms of co-operation between the authorities (the Finnish Immigration Service [Migri], the Department of Forensic Medicine at the University of Helsinki, the police and the embassies). It is also reflected in the high number of tests. According to the available statistics, testing peaked in 2010 with 752 tests, and the percentage of applications for family reunification filed by recipients of international protection that have resulted in testing has remained high: between 25 and 40 per cent annually. The system in Finland and in the other Nordic countries is centralized, legalistic and relatively transparent (Heinemann et al. 2013). What separates Finland from most countries using DNA testing for family reunification is quite elementary: the DNA test is an option offered to the applicants and paid for by Migri. Hence, the applicants do not have to organize the testing or pay

\footnotetext{
2 The appellants come from 27 different countries, but the predominance of Somalis becomes even more predominant when we note that the second most common country of origin is the Democratic Republic of the Congo with only 17 cases, followed by Afghanistan and Iraq with 5 cases. The Somalis have been targeted also, for example, in Denmark (Taitz et al. 2002: 26-27), Hungary (EMN 2009), and the United States (Villiers 2010). In Germany, the Federal Foreign Office has published a list of over 40 countries whose documents are not acknowledged (Heinemann and Lemke 2015: 17). These countries are suspect in Finland, too, but due to the specific immigration patterns in Finland, few immigrants from them apply asylum. Therefore, the ethnic bias in Finland is clear-cut.
} 
for it by themselves. On the other hand, they cannot initiate or demand testing, which partly explains the large number of appeals made in the appellate court (see below).

Many studies have shown that the use of DNA testing is discriminatory (Taitz et al. 2002; Villiers 2010; Holland 2011; Dove 2015). It was introduced in Finland, however, as a measure that could safeguard non-discrimination by offering an alternative opportunity to people without acceptable documents. One of the incentives for deploying DNA analysis was that a clear majority of applications had been rejected, among them a considerable number filed by unaccompanied minors (Helén and Tapaninen 2013; Tapaninen and Helén 2015). Before the initiation of DNA testing in Finland, the people most concerned, that is, Somalis, were informed of its imminent introduction in discussions organized by the Directorate of Foreigners, Migri's predecessor. Almost two decades later, an official reminisced that the response had been "totally positive", and no ethical questions had been raised, mentioning an elderly person who had condensed the potential of DNA analysis into the words, "Because we cannot get documents, passports, let the DNA be our passport!" The impetus, therefore, was twofold: the prevention of fraudulent claims and the reunification of families whose ties could not be verified otherwise. The success of the latter goal was expressed in a Migri newsletter (Maahanmuuttovirasto 2008) that reflected the normalisation of DNA testing: "DNA testing has unified a record number of immigrant families."

The routinisation of DNA also has other, indirect consequences. In the early days of DNA testing, the Annual Report of the Directorate of Foreigners anticipated that the investigation of "blood relationships" would ensure "the correct reunification of families", while "awareness of the availability of DNA testing also forestalls applications submitted on false grounds" (Ulkomaalaisvirasto 2001). A decade later, this view was repeated, with confidence, in Finland's response to the European Commission's Green Paper (2011): “The preventive effect of DNA testing has for the most part been achieved and no discrepancies are found with the initial information provided." In other words, the authorities think that the option of DNA analysis also works by inducing self-constraint in potential applicants. According to a Finnish official, when information spread that DNA testing would be applied, "the cases [of exclusion] were fewer because the applicants knew that they would be tested, and there is a pre-emptive effect, which was, actually, the initial purpose". This presumption of a self-selective function entails confidence in people's rational understanding of genetics, summarized by another official:

Of course, one could say that tests were not taken by the people who knew that the results would not be positive. And that's how it has been ever since. Only by accident has it turned out that the people discovered they weren't [biological relatives]. 
Because DNA testing is offered as an option, and organized and paid for by Migri, the burden of proof is not placed solely upon the applicants. According to report, few people have refused the test. A lawyer related that her clients' attitudes have been neutral, "Nobody has opposed or even found the idea strange." Instead, she added, they are mostly disappointed when they have not been offered the option of testing and the decision has been negative. In the present conjuncture of increasing demands and obstacles, DNA testing may be viewed as a right for applicants awaiting decisions, maybe for years and in vain.

The appeals filed at the Administrative Court of Helsinki testify to the potential of DNA testing for the people concerned. In 130 out of 207 appeals, the appellants demanded testing or gave their consent in advance. This derives partly from the fact that the applicants cannot request testing in earlier stages of the process (see above). In comparison, only in four cases had families refused testing, and in another 18 cases the formal opportunity for a test had been provided but, according to the appeals, the journey to the nearest Finnish Embassy had been an insuperable obstacle. In the remaining 51 cases, the restricted potential of the 'material evidence' is evident: DNA analysis had already verified the alleged family ties, but the application had been rejected because the authorities had not been convinced about the authenticity of family life (see below; for a detailed analysis, see Halme-Tuomisaari et al. 2018). In light of the court cases, it is apparent that DNA testing is not compulsory in a straightforward way in Finland, as compared to most countries, yet it does provide applicants with a means for gaining credibility - against all the odds.

Since the beginning of DNA testing, there have been two intertwined rationales justifying its use for family reunification in Finland: securing human rights and combating fraud (Helén and Tapaninen 2013; Tapaninen and Helén 2015). As the purpose has been compilation of the facts in order to 'get closer to the truth', these objectives are not perceived to be conflicting. Yet the reliance on the interplay of diverse forms of evidence undermines the decisions, leaving them undetermined and open to restrictive trends in migration policies at large.

\section{From genetic relatedness to family ties}

The Fact Sheet on DNA Testing (Maahanmuuttovirasto 2014) reads: "DNA testing can be used to determine with great certainty whether persons are biologically related to each other." But what does it actually prove? The Aliens Act does not spell out why (and how) the evidence of genetic relatedness can form the basis for family reunification. While the criteria of eligible families are 
only vaguely defined in legislation, in investigations they are delineated by varied technologies. On a more general level, the interpretations are embedded in "common-sense biologisms that comprise an 'invisible' realm of Euro-American certainties" (Franklin 1995: 168). One indication of this duality is the tendency to refer to 'biological facts' in a way that acknowledges and even emphasizes the importance of 'social' family ties. This duality is habitually, even 'naturally', taken for granted because it is rooted in historically and culturally specific understandings of EuroAmerican kinship (see, e.g., Schneider 1980; Franklin and McKinnon 2011). A case in point is the task of the decision-makers to translate the biological into the socially acceptable make up of relatedness. Consequently, the proceedings entail an oscillation between geneticized and degeneticized conceptualisations (Salazar 2012). This fluctuation forms the basis for the fabrication of the idea of a 'true' family within migration management regimes.

In DNA kinship testing, the result is "a relationship of genetic relatedness between at least two samples" (Anderlik and Rothstein 2002: 215, emphasis added). This phrasing brings to the fore the fact that the molecular-biological data is meaningless by itself and has to be invested with cultural conceptions and social forms to have an effect (Palmie 2007). The leap from the 'relatedness between samples' to the conception of a 'true family' is historically and ideologically motivated. Obviously, laboratory reports cannot confirm the existence of families but only the probability of genetic relatedness. Furthermore, the technical details do make a difference in the interpretation of the results: the number of DNA markers, reference populations and thresholds of doubt can vary (Barata 2012; M'charek 2000). From the geneticists' point of view, the truth of their analysis is established by probabilities that do not add up to simple rejections or confirmations. In Migri, these are translated into evidence of the existence of a family. At this point, the evidence can lead to only two possible conclusions: yes or no.

The conversion of the 'genetic relatedness between samples' into the proof of eligible families has become commonplace to the point that it is not seen as a translation at all. This is illustrated by the image that explains the interpretation of the paternity test to the general public. 


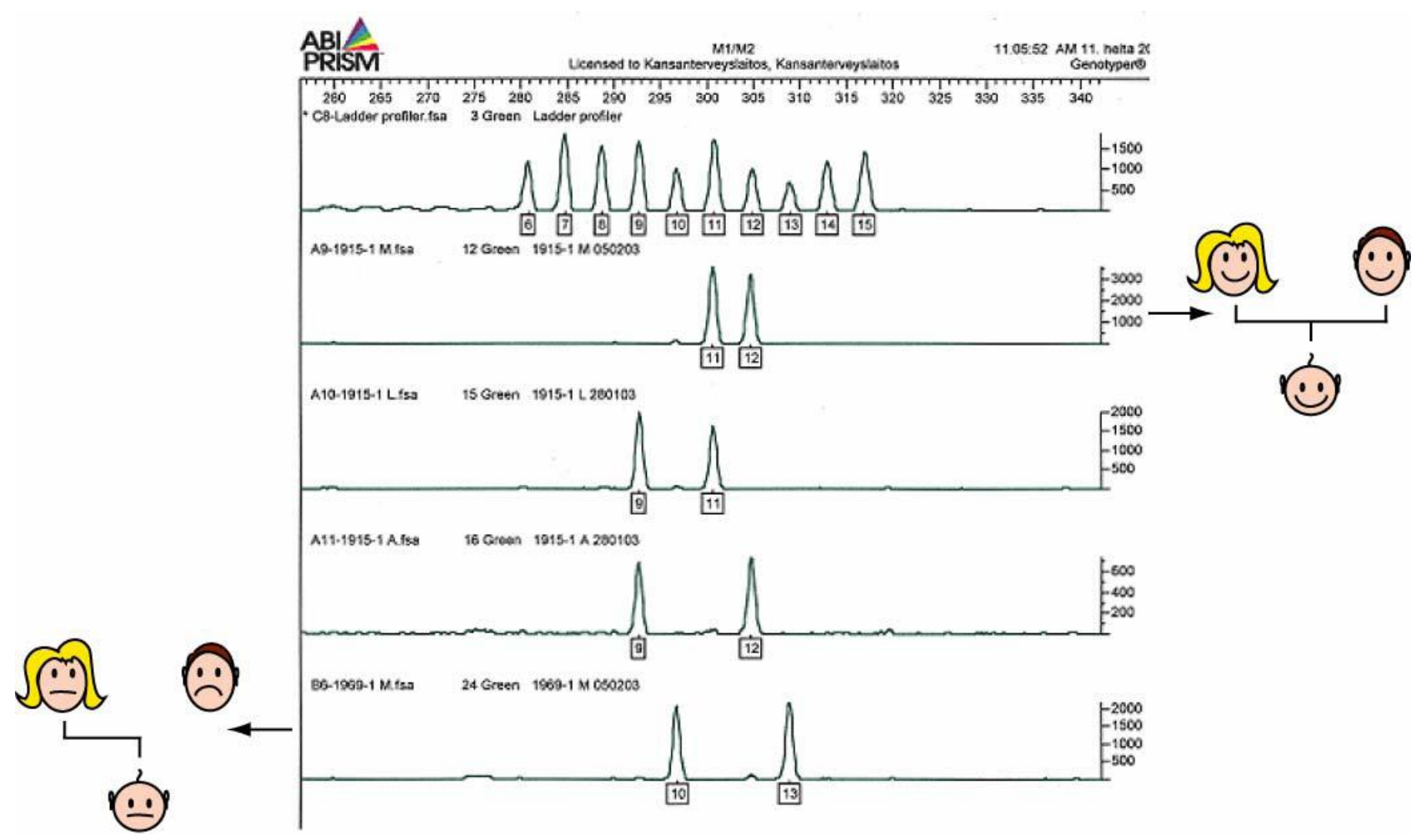

Image 1. An example of the results and interpretation of DNA analysis. (C) The National Institute of Health and Welfare.

The image of non-exclusion and exclusion in this sketch beautifully captures the translation of genetic relatedness into evidence of the existence of families. Through this snapshot-like visualization, the evidence of genetic relatedness in the form of markers, on the one hand, and an image of families, complete with faces and expressions instead of the conventional symbols of triangles and circles, are brought side by side, simplified and made literally flat (see Latour 1986: 21-26). However, this connection is not spelled out in the legislation or administrative guidelines. Biological relationships are absent from the wording of the Aliens Act, save for the two sections on DNA testing that refer to "material evidence of family ties". Instead of parents, the legal personae include "guardians" and "de-facto guardians". To complicate things further, the classification of family members is relatively extensive in Finland and not limited only to bounded nuclear families. Pursuant to Section 52 of the Aliens Act, unaccompanied minors can be reunited with their siblings if "the parents are dead or their whereabouts are not known". This is not possible, for example, in Austria and Germany (Heinemann et al. 2013). In Finland, the types of relations that can be verified through DNA analysis include a child's relationship to foster parents if they are also genetically related (for example aunts, uncles or grandparents). Hence, the extended paternity testing has additional potential, and therefore 'kinship testing' may be more apt a term than 'parental testing'. Contrary to what has been suggested by many interpretations of DNA testing, neither the legislation 
nor the technology inevitably reduce relatedness to biological nuclear families. Rather, because of the legal notions of eligibility and the potential for broad uses of DNA analysis, more extensive kinship ties can in principle be taken into consideration in decision-making.

In the absence of legalised marriage and birth certificates, marital ties can also be investigated by testing biological relatedness via common children. ${ }^{3}$ There may not be many cases of this but the potential is wide-ranging. Here, new technology as such is not the issue but, rather, the use of DNA testing for new purposes, thereby stretching the applicability of the technology. In the verification of conjugal relations, procreation - confirmed through DNA analysis - can even become a necessity. One lawyer related a story of a couple whose application for family reunification was rejected because they had refused DNA testing. He vaguely referred to "cultural reasons" behind the refusal. The husband was in Finland and his pregnant wife abroad, awaiting the decision, and the lawyer believed that Migri had postponed the decision until the child was born in order to prove or disprove the marital bond through parental testing. One of our informants, an interpreter, was deeply affected by a parallel case involving the verification of a marital tie via DNA testing. The mother had taken her baby to the Finnish Embassy for DNA testing, but the baby had died after the sample was taken. Parenthood was verified in the laboratory report and the residence permits were granted. "When she arrived in Finland, she was asked: 'Where's the baby?' But all she had to show was his death certificate." The interpreter exclaimed: "He was so small... Why couldn't he die before the test?" Yet he quickly added: "But luckily he didn't because this baby was the only piece of evidence she had of her relationship to her husband."

By requiring DNA analysis to prove alleged kinship ties, Finnish immigration authorities also test the credibility of the applicants. The authorities seem to be oriented by a default suspicion of applicants and their claims, and DNA testing thus also tests the trustworthiness of both (Tapaninen and Helén 2015; Hall and Naue 2015). This tendency is at its clearest when parental testing bleeds into relations that are by definition not based on genetic ties. In addition to testing affinal ties created though marriage, ties of fosterage based on care can also be confirmed or at least disproved by the laboratory analysis. An official described the role of such a usage in administrative routines: "In the case of a biological child the presumption of care is much stronger than in the case of children who are [only] relatives." She continued by referring to foster children, who are often said

\footnotetext{
${ }^{3}$ We have not encountered information on the testing of marital relationships or fosterage through DNA analysis elsewhere, except for Canada (Canadian Council of Refugees 2011). In France, DNA analysis concerns only maternal filiation while paternity tests are excluded, "to avoid embarrassing revelations" (Murdock 2008: 1511).
} 
to be nieces or nephews, and thus biologically related. For this reason, they can be offered an option of DNA testing, too:

In the case of foster children DNA testing is not very useful. Even if we can test that she is a niece, this does not tell us whether the relation of care is real. But it does tell... it helps us track down the story. If the alleged kinship relation does not exist, then obviously the other narrative about this child is not true, either. Thus, it does provide information that can be grounds for a rejection. ... The test does not do away the challenges of our interpretations. It is just one part [of evidence], albeit providing absolute data.

Availability of 'absolute data' provides a yardstick of credibility. According to a lawyer, this kind of understanding is quite common: "If the result of the DNA analysis shows that there isn't a biological relation, the narrative, even a coherent narrative of family life, does not lead to a positive decision." The extended paternity test almost inevitably works as a biological lie detector, too (Lynch et al. 2008; Weiss 2011; Hall and Naue 2015). The use of DNA analysis to prove the genuine nature of marriages or marriage-like relationships illustrates this. In Finland's response to the Green Paper (2011), the potential of DNA testing is linked to the prevention of forced marriages. Marriages between close relatives are mentioned as an example of a risk group that needs to be identified, and in these cases, "closer investigations" could be carried out "using interviews and possibly DNA tests". DNA analysis is not the "trump card" in Finland, as it is in Germany (Heinemann and Lemke 2012; 2015), but it has an extended potential.

\section{In search of good markers}

Above, we showed how DNA analysis helps to make immigrants legible and how it can be extended to provide evidence of their trustworthiness in general, including in cases of relations based on care. However, the questions asked in Finnish procedures are more complicated, and the verification of family ties via DNA analysis is neither a sufficient nor a necessary piece of evidence. In this section, we discuss how translations also work in the other direction, from the factual information of DNA analysis to the compilation of facts outside the laboratory. We argue that the availability of DNA analysis serves as a model for the gathering and interpretation of other kinds of data, and therefore works as the "gold standard" (Lynch 2003) of certainty. The reports of DNA analyses are weighed together with other pieces of evidence that are believed to establish 'true' relatedness, albeit in a more indefinable form. 
Lengthy interviews of all family members at different stages of the immigration process are the primary method of investigation. Migri's press release (2008) announcing the record number of refugee families reunified via DNA testing (mentioned above) also states that "a purely biological relationship is not, however, sufficient for a positive decision on residence permit without the background of a genuine, permanent family life" (emphasis added). This statement is followed by a reference to a foster child who can get a residence permit if identifiable "as an integral member of the family". This excerpt as well as other documents and the expert interviews we compiled all exemplify the oscillation between geneticized and de-geneticized notions of relatedness (Salazar 2012).

Hence, the question extends beyond quantifiable genetic ties. Immigration authorities seem to need another type of information to prove the existence of a family eligible for reunification. An immigration lawyer summarized the shift in the use of DNA testing as follows: "DNA was at the centre when it was first applied, it was the definitive factor and it was extremely easy and comfortable for everybody because it was so clear." She remarked that nowadays a negative decision can be based on other reasons, "on grounds that can be made up". A Finnish Somalian man captured the same tendency by repeating a simple rhetorical question three times during our interview with him: "Why is DNA not enough?"

Rejections are often based on inconsistencies in narratives or, rather, in narrative minutiae. In one interview, an official referred to certain details that are good 'markers' in interviews with applicants:

We ask questions about the details of family life, about housing, schools, the everyday life of the family. However, in the Somali context the children often cannot attend school regularly, the parents may not have jobs, and the quotidian life of the family can be scattered, in a way. It is very difficult to find markers with which to piece together an image of family life. And they may all be illiterate with a tenuous conception of time [compared to ours]; well, we are sometimes really in trouble, and expertise is called for in evaluating what kind of questions to ask and how to formulate them.

The official chose the vocabulary of DNA testing on purpose. This shift between two types of rhetoric - the one affirmative of molecular biology, the other reflecting the normative talk of generic families - is illustrative of the tendency to translate the criteria of scientific knowledge into 
another form of knowledge that seeks exact answers about family life. For this purpose, Migri focuses on "detailed and unexpected questions" (Maahanmuuttovirasto 2012). The interpretation guidelines published by Migri (Maahanmuuttovirasto 2013) emphasize, however, that answers can also be dubious if they are too consistent. In the decisions of the Administrative Court of Helsinki there is ample evidence of the minutiae that is the focus of oral hearings. These include not only schooling and work but also the specifics of abodes, material surroundings, colours, and electricity and water supplies. In the search for precise evidence, the questions also concern numbers, dates and ages, despite the possible illiteracy or youth of the interviewees. It is obvious, however, that detailed questions presented to all family members, children included, at different stages of the process may easily lead to inconsistencies in answers. Nonetheless, in the eyes of immigration officials, incoherence in the detailing of these minutiae may be regarded as evidence of fraudulent claims about family life.

The demand of permanence is certainly paradoxical in the case of people on the move. The requirement of consistent answers to exact questions starkly contrasts with the diversity of experiences of applicants separated by diasporas. As the immutable, consistent details sought by the authorities may have little connection with their mutable lives, it is difficult for them to convince the authorities of the 'genuine' and 'permanent' basis of family life. The questions asked by the immigration authorities are inevitably directed by an imagined narrative of genuine family life through cultural translation (Good 2011; Carver 2014; Pellander 2015). Thus, another collective emerges: one that is an 'elsewhere', inhabited by other people, typically the 'Somalis' with their illegible kinship configurations. Yet both in the court decisions we analyse and in our interviews with officials, concrete minutiae are singled out as relevant to decision-making, even those details that are not directly related to family life but rather consist of snapshot-like elements such as trees, colours and dates. In the case of people with a refugee background - that is, the majority of people subjected to DNA testing - such an emphasis on detail is in line with the logic of DNA testing. Because of perceived strangeness and inherent suspicion, the digging up of truth is based on singular facts like genetic markers and the aforementioned 'markers' in oral hearings. Eventually, the results of DNA analysis are also inserted as an element in this plausible narrative (see M'charek 2008; Kruse 2012) of family life, part of the grounds for estimating whether family life has been permanent enough and genuine enough. Alternatively, and quite often, the option of testing is not even offered because the other criteria of family life are not met. 


\section{Conclusions}

What does DNA testing do in the context of immigration management in the Global North? We have sought answers to this question by studying two topics: First, we looked at the impact of DNA analysis as a provider of facts and knowledge used as evidence in the administrative and legal context of immigration management. Second, we examined how DNA testing contributes to making up families and other collectives in which migrant individuals are associated in the investigations and decision-making by immigration authorities.

Our analysis focused on Finnish procedures and rationales of family reunification in which DNA analysis provides just one piece of evidence. In Finland, DNA testing has been an unchanging and widely accepted technique since 2000 . The benefits of exact knowledge are appreciated by many in immigration management, in NGOs and among the immigrants and their family members. Lawyers and people working in the NGOs continue to see it as a guarantee of the applicants' rights. In immigration management, DNA testing reduces the complexity of family migration by providing precise information and administrative convenience for decision-making, and it has considerable benefits in the containment of the 'inflows' of immigrants. For the applicants concerned, it may be a way to gain credibility or even the only option for family reunification, as the appeals to the Administrative Court of Helsinki testify. For people on the move, there are more difficult complications and perils on the way, and, in this context, the exigency of DNA testing is not the principal constraint. The two rationales of DNA testing - border control and human rights - still coexist, which may explain why its use has not been challenged at large.

In comparison with other countries, in Finland DNA analysis is seen as an important resource for both the authorities and the applicants. Despite this, the Finnish system is characterized by fundamental ambiguity in the use of DNA analysis, as our study shows. First, the results are equivocal in the sense that laboratory analysis does not provide definitive proof of the existence of a family. On the contrary, the nature of the putative family and the claimants' intentions are investigated in oral hearings by focusing on precise facts of family life and personal histories. Yet the proof sought from interviews is modelled on the ideal of evidentiary precision or the 'truth knowledge' (Salazar 2011) established by DNA analysis. Hence, the criteria of truth are extended from the realm of scientific proof to the realm of narratives. 
DNA testing is inclined to many translations and extensions when applied to family reunification, and therefore it may provide an answer to a variety of questions. Reading the evidence of "genetic relatedness between samples" (Anderlik and Rothstein 2002) as proof of the existence of a family tie is already a translation. Moreover, the results can be stretched further by translating them into proof regarding questions that are not directly related to genetic relatedness. When immigration authorities use DNA analysis in investigations of applicants and for decision-making, results based on probabilistic reasoning are translated to serve the binary administrative logic. Since the procedures take place in an administrative and political ethos of generalized suspicion (Fassin 2005; Aas 2011; Andersson 2014; Tapaninen and Helén 2015), DNA analysis is embedded in the ubiquitous "technology of doubting" (Good et al. 2015). In this context, suspicion can outweigh any form of evidence.

Throughout this paper we have traced the quest for truth in Finnish immigration management in which DNA is but one piece of evidence. Against the background of insecurity, mutability and mobility, DNA analysis stands out as the most objective piece of evidence both for the claimants and the decision-makers. As unchangeable information on the genetic make-up of the sampled people can travel between laboratories and authorities, and span time and space, DNA analysis is akin to an immutable mobile (Latour 1986). In the managing of family reunification, DNA reports seem to be immutable mobiles par excellence. However, the dynamics of doubt and proof are always on the move in immigration regimes, and DNA testing tends to be extended and translated, as we have shown. Therefore, the significance of genetic information is open to interpretation. Furthermore, the purposes and consequences of DNA testing are not stable, but vary with changing immigration regimes, meaning that, ultimately, the most absolute, seemingly immutable piece of evidence is inherently mutable (on mutable mobiles, see Mol and Law 1994). The many technologies that aim to make people legible also make them inherently illegible.

DNA analysis does not only provide evidence and the model of truth in the practices by which immigration authorities investigate immigrants and make decisions upon their cases; vis-à-vis other types of proof, it is also involved in making up collectives and then linking individuals to them. Different technologies produce different configurations of the individual and the family, which are eventually co-ordinated into a version that counts as evidence supporting inclusion or exclusion. The rationales and administrative procedures of family reunification make up many collectives, however, beside the family: 'the Somalis', 'the refugees' and 'the suspect aliens' are three that have been mentioned here. These collectives exist and are significant only at the borders, that is, in the 
context of the 'entry game' between the immigration authorities and the migrating people. Thus, the collectives in question - Somalis, refugees, aliens and families - are political and administrative creations, which are overlapping, imbricated and enmeshed with each other. For this reason, these collectives and categories of human beings are not supported by a strong looping effect that would vindicate and clearly define them as this or that kind of collective (see Hacking 2007). Instead, they all tend to be continuously unfolding: blurry, volatile and contestable within the maze of doubt and proof prevailing in institutions and practices of immigration control. The family is a moving target, far removed from the abstract idea of 'the natural and fundamental' essence that, for example, the Universal Declaration of Human Rights insinuates. When the immigration authorities of the Global North delineate families as eligible for reunification, they actually do not produce family but disseminate it, engendering something contingent, indefinite, even arbitrary.

The more obstacles there are in the way of family reunification, be they requirements related to personal income and property, restrictions in legislation or administrative demands, the more valuable the option of DNA testing can become for applicants. Yet, with the changing migration regimes and 'flows' of migrants, the weight of DNA analysis also shifts. Since 2010, legislative amendments have made family reunification increasingly difficult in Finland, starting from the new requirements set for the filing of applications. Consequently, the 'profiles' of applicants have also changed, and there is less need for the extended use of DNA testing, for example in the case of foster children (Fingerroos et al. 2016).

Following the so-called refugee crisis of 2015, the criteria of family reunification were tightened further in Finland, in particular by setting a considerably higher level of 'stable income' as a requirement for family reunification. It is quite obvious that the question of proof, including DNA analysis, will no longer be at the centre of decision-making. Or, rather, the veracity of the alleged family ties will probably still be scrupulously examined, but fewer people will have enough financial and social resources to be considered. For example, of the record number of 3,000 unaccompanied minor asylum seekers in 2015, most were granted residence permits. Yet they are unlikely to be reunified with their families because it is highly improbable that their incomes will meet the requirements. The restrictive trend has affected the actual role of DNA analysis in family reunification. It also compels us to reconsider our analysis of the dynamics of doubt and proof. Indeed, our first critical views of introduction and deployment of DNA testing (Helén and Tapaninen 2013; Tapaninen and Helén 2015) are becoming more hesitant, and we are now inclined to concur that DNA testing may be the best option for many. 
For the time being, we give the final words to a Finnish Somalian woman, who was impatiently waiting for the interviews and DNA testing to be able to get her husband, and the father of her children, to Finland. She observed: "I have never told this to anybody, but I think they are using the DNA test just to show that they are serious about this thing."

This study was funded by the Academy of Finland (grant number 135266) and the Kone Foundation.

\section{Bibliography}

Aas, K.F. 2006. 'The body does not lie': Identity, risk and trust in technoculture. Crime Media Culture, 2 (2): 143-158.

Aas, K. F. 2011. Crimmigrant bodies and bona fide travellers: Surveillance, citizenship and global governance. Theoretical Criminology 15(3): 331-346.

Anderlik, M. and M.A. Rothstein. 2002. DNA-based identity testing and the future of the family: A research agenda. American Journal of Law and Medicine 28 (2-3): 215-232.

Andersson, R. 2014. Time and the migrant other: European border controls and the temporal economy of illegality. American Anthropologist 116 (4): 795-809.

Barata, L. 2012. Genetic Testing in Immigration for Family Reunification: Ethical, Legal and Social Implication. Dissertation, University of Washington.

Carver, N. 2014. Displaying genuineness: cultural translation in the drafting of marriage narratives for immigration applications and appeals. Families, Relationships and Societies 3 (2): 271-86.

Canadian Council of Refugees. 2011. DNA Test: A barrier for speedy family reunification. http://ccrweb.ca/files/dnatests.pdf. Accessed 20 Oct 2016.

Dijstelbloem, H. and Meijer, A. (eds.) 2011. Migration and the New Technological Borders of Europe. Basingstoke: Palgrave Macmillan.

Dove, E.S. 2014. Back to blood: The sociopolitics and law of compulsory DNA testing of refugees. University of Massachusetts Law Review 8 (2): 466-530. 
Esbenshade, J. 2010. An Assessment of DNA Testing for African Refugees. Washington, DC: Immigration Policy Center.

European Commission. 2011. Green paper on the right to family reunification of third-country nationals living in the European Union (Directive 2003/86/EC). EUR-Lex. Official Journal of the European Union, 735: 1-12.

European Migration Network. 2008. Family Reunification: Synthesis Report. http://emn.intrasoftintl.com/html/index.html. Accessed 24 April 2014.

European Migration Network. 2009. Ad-Hoc Query on Conducting Other Investigations (Using a DNA Test) in Family Reunification. http://emn.intrasoft-intl.com/html/index.html. Accessed 24 April 2014.

European Migration Network. 2010. Policies on Reception, Return and Integration arrangements for, and numbers of Unaccompanied Minors: An EU comparative study. DOI: 10.2837/10006 European Migration Network. 2012a. Misuse of the Right to Family Reunification: Marriages of Convenience and False Declarations of Parenthood. http://www.emn.at/wpcontent/uploads/2012/07/0a_EMN_Misuse_Family_Reunification_Study_PUBLICATION.pd f. Accessed 24 April 2014.

European Migration Network. 2012b. Misuse of the Right to Family Reunification: Marriages of Convenience and False Declarations of Parenthood - National Contribution of Finland. https://ec.europa.eu/home-affairs/sites/homeaffairs/files/what-wedo/networks/european_migration_network/reports/docs/emn-studies/familyreunification/fi_20120327_familyreunificationstudy_final_en.pdf. Accessed 24 April 2014. European Migration Network. 2016. EMN Hoc Query on Checking identity and family relationships in case of family reunification with a beneficiary of international protection. https://ec.europa.eu/home-affairs/sites/homeaffairs/files/what-wedo/networks/european_migration_network/reports/docs/ad-hoc-queries/ad-hoc-queries2016.1074_nl_checking_identity_and_family_relationships.pdf. Accessed 24 Sep 2016. European Migration Network. 2017. Family Reunification of Third-Country Nationals in the EU plus Norway: National Practices. https://ec.europa.eu/homeaffairs/sites/homeaffairs/files/00_family_reunification_synthesis_report_final_en_print_ready _0.pdf. Accessed 10 Aug 2017.

Eurostat. 2016. Residence Permits Statistics. http://ec.europa.eu/eurostat/statisticsexplained/index.php/Residence_permits_statistics. Accessed 10 June 2017.

Fassin, D. 2005. Compassion and repression: The moral economy of immigration policies in France. Cultural Anthropology, 20 (3): 362-87. 
Fassin, D. and D. Halluin. 2005. Truth from the body: Medical certificates as ultimate evidence for asylum seekers. American Anthropologist 107 (4):597-608.

Franklin, S. and S. McKinnon (eds.) 2001. Relative Values: Reconfiguring Kinship Studies. Durham: Duke University Press.

Fingerroos, O., A-M. Tapaninen and M. Tiilikainen. 2016. Johdanto. In Perheenyhdistäminen: Kuka saa perheen Suomeen, kuka ei ja miksi? eds. O. Fingerroos, A-M. Tapaninen and M. Tiilikainen, 7-20. Tampere: Vastapaino.

Finnish Immigration Service. 2008. DNA Analysis Has Unified a Record Number of Immigrant Families.

http://www.migri.fi/for_the_media/bulletins/press_releases/press_releases/1/0/dna testing ha s_united_a_record_number_of_immigrant_families_13968. Accessed 18 Sept 2015.

Finnish Immigration Service. 2014. Fact Sheet: DNA test in connection with a residence permit application.

https://migri.fi/documents/5202425/6160286/DNA+TEST+in+connection+with+a+residence +permit+application+\%28en\%29. Accessed 15 March 2015.

Good, A. 2011. Witness statements and credibility in the British asylum courts. In Cultural Expertise and Litigation, ed. L. Holden, 94-122 New York: Routledge.

Good, A., D. Berti and G. Tarabout. 2015. Introduction: Technologies of Doubt in Law and Ritual. In Of Doubt and Proof: Ritual and Legal Practices of Judgment eds. D. Berti, A. Good and G. Tarabout, 1-18. Farnham: Ashgate.

Hacking, I. 2002. Historical Ontology. Cambridge, MA: Harvard University Press.

Hacking, I. (2007) Kinds of people: Moving targets. In Proceedings of the British Academy, Vol. 151: 2006 Lectures, 285-318.

Hall, K. and U. Naue. 2005. Austria: DNA profiling as a lie detector. In Suspect Families: DNA Analysis, Family Reunification and Immigration Policies, eds. T. Heinemann et al., 55-78. Farnham: Ashgate.

Halme-Tuomisaari, M., A-M. Tapaninen and H. Aunela. 2018. Where's the well: DNA evidence, personal narratives and unpredictability in Finnish family reunification. Migration Studies, DOI: $10.1093 /$ migration/mny002

Heinemann, T. and T. Lemke. 2013. Suspect families: DNA kinship testing in German immigration policy. Sociology 47 (4): 810-26.

Heinemann, T. and T. Lemke. 2014. Biological citizenship reconsidered: The use of DNA analysis by immigration authorities in Germany. Science, Technology and Human Values, 39 (4): 488510. 
Heinemann, T., U. Naue and A-M. Tapaninen 2013. Verifying the family? A comparison of DNA analysis for family reunification in three European countries (Austria, Finland and Germany). European Journal of Migration and Law 15 (2): 183-202.

Heinemann, T., I. Helén, T. Lemke, U. Naue and M. Weiss (eds.) 2015. Suspect Families: DNA Analysis, Family Reunification and Immigration Policies. Farnham: Ashgate.

Helén, I. 2014. Biological citizenship across the borders: Politics of DNA profiling for family reunification. Distinktion: The Scandinavian Journal of Social Theory 15 (3): 343-360.

Helén, I. and A-M. Tapaninen 2013. Closer to the truth: DNA profiling for family reunification and the rationales of immigration policy in Finland. Nordic Journal of Migration Research 3 (3): 153-161.

Holland, E. 2011. Moving the virtual border to the cellular level: Mandatory DNA testing and the U.S. refugee family reunification program. California Law Review, 99 (6): 1, 635-81.

Jasanoff, S. 2004. The idiom of co-production. In States of Knowledge: The Co-Production of Science and Social Order, ed. S. Jasanoff, 1-12. London: Routledge.

Kelly, T. (2015) Afterword. In Of Doubt and Proof: Ritual and Legal Practices of Judgment eds. D. Berti, A. Good and G. Tarabout, 183-192. Farnham: Ashgate.

Kruse, C. 2012. Legal storytelling in pre-trial investigations: Arguing for a wider perspective on forensic evidence. New Genetics and Society 31 (3): 299-309.

Latour, B. 1986. Visualization and Cognition: Thinking with eyes and hands. Knowledge and Society: Studies of Culture Past and Present 6: 1-40.

Lynch, M. 2003. God's Signature: DNA profiling, the new gold standard in forensic science. Endeavour 27 (2): 93-7.

Lynch, M., S.A. Cole and R. McNally. 2008. Truth Machine: The Contentious History of DNA Fingerprinting. Chicago: University of Chicago Press.

Maahanmuuttovirasto. 2012. Vuosikertomus 2011. http://issuu.com/maahanmuuttovirasto/docs/vuosikertomus_2011. Accessed 24 April 2014.

Maahanmuuttovirasto. .2013. Oleskelupa perhesiteen perusteella. Unpublished memorandum 13.5.2013. Helsinki: Maahanmuuttovirasto.

M'charek, A. 2000. Technologies of Population: Forensic DNA Testing Practices and the Making of Differences and Similarities. Configurations 8 (1): 121-158

M'charek, A. 2008. Silent witness, articulate collective: DNA evidence and the inference of visible traits. Bioethics 22 (9): 519-28.

Mol, A. and J. Law. 1994. Regions, Networks and Fluids: Anaemia and Social Topology. Social Studies of Science 24 (4): 641-671. 
Murdock, T.R. 2008. Whose child is this? Genetic analysis and family reunification immigration in France. Vanderbilt Journal of Transnational Law, 41 (5): 1503-34.

Noll, G. 2016. Junk Science? For Arguments against the Radiological Age Assessment of Unaccompanied Minors Seeking Asylum. International Journal of Refugee Law 28 (2): 234250 .

Palmie, S. 2007. Genomics, Divination, "Racecraft”. American Ethnologist 34 (2): 205-222.

Pellander, S. 2014. “An Acceptable Marriage”. Marriage Migration and Moral Gatekeeping in Finland. Journal of Family Issues 36 (11): 1472-1489.

Ruffer, G. 2011. Pushed beyond recognition? The liberality of family reunification policies in the EU. Journal of Ethnic and Migration Studies 37 (6): 935-951.

Schneider, D. 1980. American Kinship: A Cultural Account. Chicago: University of Chicago Press. Scott, James C. 1999. Seeing Like a State: How Certain Schemes to Improve the Human Condition Have Failed. New Haven: Yale University Press.

Smith, T. and L. Brownlees. 2011. Age assessment practices: a literature review \& annotated bibliography. New York: UNICEF.

Taitz, J., J.E.M. Weekers and D.T. Mosca . 2002. The last resort: Exploring the use of DNA testing for family reunification. Health and Human Rights 6 (1): 20-32.

Tapaninen, A-M., M. Halme-Tuomisaari and V. Kankaanpää. 2017. Mobile lives, immutable facts: family reunification of children in Finland. Journal of Ethnic and Migration Studies, DOI: $\underline{10.1080 / 1369183 X .2017 .1405725}$

Tapaninen, A-M. and I. Helén. 2015. Finland: Securing Human Rights, Suspecting Fraud. In Suspect families. DNA analysis, family reunification and immigration policies, eds. Torsten Heinemann et al, 33-53. Fernham: Ashgate.

Ulkomaalaisvirasto. 2001. Ulkomaalaisviraston vuosikertomus 2000. Helsinki:

Ulkomaalaisvirasto.UNHCR (2008) UNHCR Note on DNA Testing to Establish Family Relationships in the Refugee Context. http://www.unhcr.org/refworld/docid/48620c2d2.html. Accessed 24 April 2014.

van der Ploeg, I. 1999. The illegal body: 'Eurodac' and the politics of biometric identification. Ethics and Information Technology 1 (4): 295-302. van der Ploeg, I. 2012. The body as data in the age of information. In Routledge Handbook of Surveillance Studies, eds. K. Ball, K.V. Haggerty K.V. and D. Lyon, 176-184. Oxon: Routledge. 
Villiers, J.D. 2010. Brave new world: The use and potential misuse of DNA technology in immigration law. Boston College Third World Law Journal 30 (2): 239-271.

Weiss, M.G. 2011. Strange DNA: The rise of DNA analysis for family reunification and its ethical implications. Genomics, Society and Politics 7: 1-19. 